Vol. 4, No. 1, February 2021

\title{
An Analysis of the Effect of Long-Term Professional Development on Teacher Engineering Self-Efficacy and Its Impact on Classroom Instruction
}

\author{
Christina Crawford, Carrie Obenland, and Carolyn Nichol \\ Office of STEM Engagement, Rice University, Houston, TX \\ Keywords: Engineering, Pre-College, K-12 Education, Project-Based Learning, Teaching Self-Efficacy, Water Sustainability, Nanotechnology, Environmental Engi- \\ neering, High-Needs Schools \\ Publication Date: February 10, 2021
}

DOI: https://doi.org/10.15695/jstem/v4i1.01

\begin{abstract}
Pre-college engineering education has gained traction in U.S. schools over the past twenty years. This growth is evident with engineering emerging as a crosscutting discipline in the Next Generation Science Standards. However, the scarcity of professional development (PD) for K-12 teachers who want to teach engineering and the few PD opportunities with the characteristics shown to improve teacher learning, i.e., contact time, long-term support, and follow-up, suggest a need for new and innovative PD offerings for K-12 teachers. We developed a 45-hour graduate course specifically for K-12 teachers to incorporate engineering into their classrooms and evaluated the effect of this long-term PD on K-12 teaching engineering self-efficacy. Additionally, this study looked at how the participants translated the course into their teaching practices. Forty-one in-service teachers participated either in a 2018 or 2019 semester-long course that combined nanotechnology content and Project-Based Learning pedagogy. Pre-post measures using Teaching Engineering Self-Efficacy Scale revealed significant gains in both cohort teachers' self-efficacy. Teachers found the course effective in building their technical skills and providing beneficial PD. This study's significant positive outcomes indicate that the course analyzed serves as a pre-college engineering education PD model.
\end{abstract}

\section{INTRODUCTION}

Approaches to teaching engineering in primary and secondary schools have been primarily ad hoc, according to the National Academies of Science (2009). The lack of a systematic and proven approach hinders the intended goal of ensuring K-12 students graduate with the ability to receive, process, and share information using scientific communication, critical thinking, and team working skills (Padilla, 1990). Teachers must understand and develop their pedagogical skills to teach engineering design. This development requires long-term professional development (PD) because teacher PD's duration and composition are tied to its effectiveness. Impromptu PD leads to inconsistent training, thus resulting in diminished and suboptimal student learning. Not only are an increasing number of teachers improperly trained to teach science, technology, engineering, and math (STEM) subjects (Hailey et al., 2005), many mathematics and science teachers are unaware of the benefits of integrated STEM learning as well as unfamiliar with engineering content and pedagogy that also include authentic problems (Valtorta and Berland, 2015).
Work from Desimone (2009) and others (Guskey, 2002; Supovitz and Turner, 2000) guided long-term PD framework. To enhance practical teaching abilities in engineering and project-based learning (PBL), teachers need active PD opportunities. For PD to be considered optimal, teachers must have a chance to 1) learn about current educational approaches to teaching science, 2) experience and question the approaches amongst peers on multiple occasions, and 3) attempt the pedagogical approaches within their teaching environments (Lieberman, 1995). Short-term or single PD offerings frequently are missing one or more of these elements of effective PD. As noted by Desimone and others, quality programs include 20 hours or more of direct contact time and are sustained throughout the school year (Desimone, 2009). Traditionally, long-term or sustained PD in K-12 education is more likely to include making observations and reflections of peer teaching practices than only building teacher content and pedagogical knowledge. Observationfocused PD is generally easier to facilitate and does not have high operational or participant costs (Boyle et al., 2005). 
Capraro's research shows that high-quality implementation of PD has a direct impact on student learning when using state assessment tests to measure effectiveness. On the other hand, low-quality implementation or PD utilization harms student outcomes (Capraro et al., 2016).

Another consideration in developing the 45-hour semester-long engineering graduate course for K-12 teachers was adult learners' need to possess the motivation and a connection to the learning environment (Wlodkowski, 1999). According to Felder et al. (2011), Wlodkowski's five attributes of successful adult motivation are also necessary factors for engineering design PD programs. The design of the PD course was aligned to all five "best practices" in professional development as follows: 1) expertise of presenters: utilized both content (research faculty and graduate student mentors) and pedagogy expertise (lead instructors with over ten years of experiences in STEM within the K-12 setting) in the course; 2) relevance of content: real-world case-studies were evaluated each year for their relevance and were focused on water sustainability which is currently a growing global issue; 3) choice: PD participants were allowed the opportunity to self-select the case-study they felt most connected to as well as how they wanted to solve this issue; 4) Praxis (action plus reflection): utilized both independent and team reflection throughout the course, completed both informally and formally via the Comprehensive Assessment of Team Member Effectiveness (CATME) system (Loignon, 2017); and 5) group work: team collaboration skills were central to the PD course. Participants were provided multiple opportunities to work with their peers and collaborate throughout the course. To prevent low implementation rates of the PD, teachers must believe in what they learn in engineering courses to translate it effectively to their students.

Studies show that teachers' self-efficacy can have a strong influence on the classroom environment and, ultimately, student outcomes (Tschannen-Moran et al., 1998; Thoonen et al., 2011). Self-efficacy, defined by Bandura (1997), is the core belief or foundation for enthusiasm, stimulus, performance, and emotional security. In education, teachers' feelings of self-efficacy, or their beliefs about their ability to impact specific learning outcomes, is associated with teachers' job satisfaction, teacher retention, along with students' academic success and self-esteem (Ashton and Webb, 1986; Bandura, 1997; Caprara et al., 2006; Skaalvik and Skaalvik, 2007). Having confidence in their teaching ability allows teachers to overcome classroom management challenges and take chances with innovative teaching strategies. Experts in educational psychology such as Anita Woolfolk Hoy "suggest that among the many beliefs teachers might hold, few are as powerful as their self-efficacy for teaching" (Hoy et al., 2009).

While numerous studies explore science teachers' self-efficacy, few studies address teaching engineering content or processes. With engineering concepts being introduced into more classrooms across K-12 grade levels, the Teaching Engineering Self-efficacy Scale (TESS) instrument (Yoon et al., 2014) was developed and validated to measure teachers' readiness to teach engineering in their K-12 classes. Because the TESS is a relatively new instrument, it has not been used in a large number of studies. However, Perkins Coppola (2019) found that pre-service elementary teachers increased in three subscales (KS, ES, and DS) but not in the Outcome Expectancy domain.

Purpose of the Study. This study evaluates the outcomes from an intervention focusing on the teachers' self-efficacy in teaching engineering. The paper intends to inform pre-college engineering educators how effective long-term in-service programs may affect K-12 teacher self-efficacy, leading to increasing engineering teaching in the pre-college space. We hypothesized that implementing a long-term PD course would enhance the self-efficacy to teach K-12 engineering, leading to the enactment of engineering within their classrooms. The following research questions were investigated:

1. When provided a semester-long PD course in engineering combining content and pedagogy, how will the K-12 teachers' self-efficacy be affected?

2. Do teachers believe they can directly affect student-engineering engagement?

\section{METHODS}

Participants. Course participants were recruited and selected from urban and suburban school districts in the greater metropolitan area. A mixture of recruitment methods were utilized to solicit the program to potential applicants. Initially, emails were sent to both principals and science teachers whose school population is comprised of over $40 \%$ economically disadvantaged students. Next, staff members conducted school visits to address specific programmatic questions and concerns. Participants were offered a stipend of $\$ 600$ for full participation in the program and $\$ 300$ worth of materials to lower barriers and allow teachers to use the course curriculum in their classrooms.

Selection Criteria. In 2018, 78 applications were received for the 25 positions in the course, and in 2019, 33 applicants were received for the 16 positions in the course. The 2019 course enrollment was capped at 16 due to funding constraints. Due to more applications being received than spots available, participants were selected based on the following criteria: 1) teaching in a high-need school district, 2) teaching students in Advanced Placement (AP) Environmental Science, Environmental Science, or Biology courses, or 3) teaching students at the secondary level. Participants 
Table 1. Course Participant Demographics.

\begin{tabular}{|c|c|c|c|}
\hline \multicolumn{2}{|l|}{2018} & \multicolumn{2}{|l|}{2019} \\
\hline \multicolumn{2}{|l|}{ Gender } & \multicolumn{2}{|l|}{ Gender } \\
\hline Male & 5 & Male & 6 \\
\hline Female & 20 & Female & 10 \\
\hline Prefer not to provide & 0 & Prefer not to provide & 0 \\
\hline Race/Ethnicity* & & \multicolumn{2}{|l|}{ Race/Ethnicity ${ }^{*}$} \\
\hline Black or African American & 8 & Black or African American & 4 \\
\hline $\begin{array}{l}\text { America Indian or Alaska } \\
\text { Native }\end{array}$ & 1 & $\begin{array}{l}\text { America Indian or Alaska } \\
\text { Native }\end{array}$ & 0 \\
\hline Asian & 3 & Asian & 3 \\
\hline $\begin{array}{l}\text { Native Hawaiian or Other } \\
\text { Pacific Islander }\end{array}$ & 1 & $\begin{array}{l}\text { Native Hawaiian or Other } \\
\text { Pacific Islander }\end{array}$ & 0 \\
\hline White & 12 & White & 8 \\
\hline Hispanic or Latino & 3 & Hispanic or Latino & 3 \\
\hline Prefer not to provide & 3 & Prefer not to provide & 0 \\
\hline Grade Level & & Grade Level & \\
\hline Elementary & 2 & Elementary & 1 \\
\hline Middle School & 4 & Middle School & 0 \\
\hline High School & 19 & High School & 15 \\
\hline
\end{tabular}

accepted into the program, outside of these criteria, were on a first-come basis until all spots were filled. All participants self-selected to apply to participate in the course. Table 1 shows the teacher demographics by gender, race/ethnicity, and teaching grade for the 2018 and 2019 cohorts. Table 2 shows the 2018 and 2019 program participants' Public Education Information Management System (PEIMS) (Texas Education Agency Snapshot, 2018) data, including the total number of students in the district or charter school system and the percentage of economically disadvantaged students. Table 3 details the course participants' teaching load while enrolled in the 2018 and 2019 graduate courses.

\section{Long-Term Professional Development Program Description.}

Program Goal. To provide teachers with long term sustained PD, a three-credit graduate course with 45 hours of contact hours, NanoEnvironmental Engineering for Teachers (NEET) was designed through brainstorming sessions

Table 2. 2018-2019 Student Demographics of by Cohort Attendees' School Districts.

\begin{tabular}{ccccc} 
School Districts' & \multicolumn{3}{c}{ In-Service Teacher Participants } \\
\cline { 2 - 5 } $\begin{array}{c}\text { \% Economically } \\
\text { Disadvantaged }\end{array}$ & \multicolumn{3}{c}{ Spring $\mathbf{2 0 1 8}$} & \multicolumn{2}{c}{ Spring 2019 } \\
\cline { 2 - 5 } & $\mathrm{N}$ & $\%$ & $\mathrm{~N}$ & $\%$ \\
$\mathbf{3}$ & 4 & 19.0 & 5 & 31.3 \\
$\mathbf{3 9}$ & 21 & 81.0 & 9 & 56.3 \\
Unknown $^{*}$ & 0 & 0.0 & 2 & 12.4 \\
\hline
\end{tabular}

"Private school demographics are not listed in the State data system and are listed as unknown (Texas Education Agency Snapshot 2018, 2019).
Table 3. 2018 and 2019 Course Attendees' Teaching Loads at Their Schools.

\begin{tabular}{lcc}
\hline \multicolumn{1}{c}{ 1 Credit Course Title } & $\mathbf{2 0 1 8}$ & $\mathbf{2 0 1 9}$ \\
\hline 8th Grade Science & 1 & 0 \\
Pre-AP Biology & 3 & 2 \\
AP Biology & 4 & 3 \\
AP Environmental Science & 4 & 5 \\
Aquatic Science & 3 & 3 \\
Elementary Science & 2 & 1 \\
Environmental Science/Systems & 6 & 3 \\
Biology & 8 & 3 \\
Physics & 2 & 3 \\
Other ${ }^{*}-$ High School & 14 & 7 \\
\hline
\end{tabular}

"High School courses with two or fewer participants were categorized as Other. Note: Participants at the secondary level may teach multiple courses per year.

and a pilot course in 2017 as described in (Nichol et al., June 2018) by faculty and staff in Rice University Office of STEM Engagement. This PD program's goal was to support teachers' pedagogical knowledge to be effective facilitators of student engineering design teams using water sustainability issues and new developments in nanotechnology to drive the design solutions. For K-12 teachers to be effective engineering teachers, they must be placed in the student role, immersed in the full engineering design process, and build their confidence and self-efficacy to bring engineering design into their classrooms effectively.

Engineering Design PD. The 2018 and 2019 NEET spring courses introduced K-12 teachers to current research on environmental nanotechnology along with grade-level appropriate learning activities, which incorporated components of engineering design from both an instructional methodology perspective, how to teach the strategy to students, as well as a guide to developing a prototype for their designs. The instruction was led by the Rice University faculty and staff, who have expertise in engineering instruction and curriculum development. Even though participants self-select to participate in NEET, there is no expectation of prior understanding of the background content or pedagogical knowledge before the course begins. Because of NEET's "come as you are" model, each participant is innately instructed differently based on getting to know each person individually. At school-levels, elementary, middle, and high, there is a mixture of content deficits from Biology to Physics that the course is designed to incorporate. NEET facilitators engaged the class in model activities and case studies but also provided the teachers time to reflect and share with peers strategies and challenges for classroom implementation. The curriculum was presented at different instruction levels to demonstrate how to scaffold content for various students' levels. NEET was listed as a Civil and Engineering graduate course, and tuition waivers for the course were secured for 
the National Science Foundation (NSF) center funding duration. The course focused on PBL to engage the participants in content enrichment, engineering design, and reflective practices. The use of real-world contexts was essential for providing relevance to the participants for facilitating PBL. The course introduced participants to the need for new designs for water sustainability during the first week of class. Groups were assigned different water-related issues (high salinity, low $\mathrm{pH}$, or high algae content) and tasked to design a mini device to fix it using any prior knowledge they may have. After modeling the developed devices to the class, participants discussed the models' limitations, consider how they believe the devices relate to practices currently in place in water treatment facilities worldwide, and predicted how they believe nanotechnology may help upgrade the process.

Peer Communication. While working in teams, participants were allowed to reflect on their communication practices and group members' practices once every two to three weeks. The CATME Project is a system of online tools that allows facilitators to support and manage project groups. The NEET course utilized the Peer-Evaluation tool in CATME to provide teammates a time-sensitive and structured way to communicate strengths and weaknesses perceived during the project (Loignon, 2017). All teammates and instructors could access the peer-assessments feedback, which created an opportunity for change in team practices and facilitator intervention when needed. Average scores from each question of the peer evaluation were emailed to each participant. This feedback loop allowed each team member to compare how they saw their contribution to how they perceived the individual's effort. The CATME online system's use allowed the course facilitator to collect and analyze student data related to team and interpersonal skills to instruct better project groups (Loughry et al., 2014).

Classroom Support. After each cohort, participants received material packages to support engineering design projects and activities with their students. Participants are encouraged to utilize either lessons directly from the PD or create their engineering curriculum based on the engineering principles and processes learned through the course. Participants can utilize engineering within their classrooms in the fall or following the spring semester; however, data is collected at the end of each fall semester.

Evaluation. Because the PD course was designed to provide teachers with authentic engineering design learning experiences that participants could bring back to their students, we wanted to know if the program improved teachers' self-efficacy in teaching engineering K-12 classrooms. While there are numerous instruments for science and mathematics teaching self-efficacy, few validated instruments have been developed to measure K-12 engineering teacher self-efficacy. These instruments include the Engineering Outreach Self-efficacy Scale (EOSS) (Fogg-Rogers and Moss, 2019), The Design, Engineering, and Technology (DET) Survey (Hon, 2011), and the Teaching Engineering Self-efficacy Scale (TESS) (Yoon et al., 2013; Yoon et al., 2014). The TESS was selected for the 2018 and 2019 participants as it was more closely aligned with our goal of preparing K-12 teachers to teach engineering in their classes versus the EOSS goal of teaching research scientists and engineers to teach engineering to K-12 students or the DET, which focused on teachers' perceptions and beliefs about engineering.

The TESS instrument consists of 23 items with a 6-point Likert scale ranging from strongly disagree to agree strongly. The scale is comprised of four subscales with Cronbach's alpha ranging from 0.89 to $0.96: 1$ ) engineering-pedagogical content knowledge (KS) or a teacher's personal belief in his/ her knowledge of engineering that will be useful in a teaching context; 2) engineering engagement self-efficacy (ES) or a teacher's belief in his/her ability to engage students while teaching engineering; 3) engineering disciplinary self-efficacy (DS) or a teacher's belief in his/her ability to handle student behaviors during engineering activities; and 4) engineering outcome expectancy (OE) or a teacher's belief in the effect of his/her teaching on students' learning of engineering. A fifth construct is overall self-efficacy in engineering teaching; this is measured by a Total Engineering Self-efficacy (TES), calculated by summing the subscore scores (ranging from 4 to 24). In both 2018 and 2019, the TESS was administered via paper on the first day of class, before any instruction, and in the same format on the last day of the course.

Also, there were two surveys administered to the teachers: a feedback survey and an implementation survey. The feedback survey was administered to teachers at the end of the course electronically within the course webpage. The survey consisted of qualitative items to evaluate the teachers' perceptions of the course's value and quality, their thoughts on which skills were strengthened through the course, and open-ended questions about what they valued and what could be improved in the course. The feedback from the end of course survey was used to inform the course developers on instructional practices for future cohorts.

The implementation survey was emailed directly to the teachers at the end of the fall semester following the spring course. The delay in the survey's administration allowed the teachers time to test and practice what they learned in PD in their classrooms the following school year. The survey consisted of four open-ended questions regarding incorporating nanotechnology-enabled water treatment topics in their classes, utilizing PBL instruction, including the engineering design process, and how their participation in the PD has influenced their students. 
Data Analysis. The TESS data was analyzed using twotailed paired t-tests to determine pre and post-instruction gains by the entire instrument and each construct. Quotes from the implementation survey were selected to present a picture of the overall feedback received.

\section{RESULTS}

Self-Efficacy in Engineering Teaching. As shown in Table 4, for the 2018 cohort of teachers, the TESS survey pre-data showed a total mean score of 4.49 and a standard deviation of 1.05 , and the post-data with a mean of 5.42 and a standard deviation of 0.58 . The paired sample t-test was performed using Excel ${ }^{\circledR}$, and results showed the difference to be significant and had a tremendous effect size $t(23)=2.07, \mathrm{p}<0.001$ with a $21 \%$ relative gain from pre- to post-program. For each subscale construct from pre- to post-survey, significant gains were also observed. As shown in Table 5, for the 2019 class, the TESS total pre-data was slightly lower at 3.93 with a standard deviation of 0.79 , and the post-data was slightly higher than in 2018 at 5.56 with a standard deviation of 0.36 and a relative gain of $41 \%$. As in the prior year, there were significant gains on each subscale construct, as shown in Table 6 .

To answer the question "Do teachers believe they can directly affect student engineering engagement?" we analyzed the Engineering Outcome Expectancy and found that for both the 2018 and 2019 classes, there were statistically significant gains in outcome expectancy from 4.42 to 5.08 in 2018 and from 3.92 to 5.16 in 2019. It is interesting to note that even though the 2019 cohort had lower overall TESS pre-data scores, their post-data scores were higher than the 2018 cohort.

To determine how teachers were using these new skills in the classroom with their students since the class ended, par-

Table 4. Changes in Teaching Engineering Self-Efficacy of 2018 Participants $(N=24)$.

\begin{tabular}{|c|c|c|c|c|c|c|c|}
\hline \multirow[t]{2}{*}{ Construct } & \multicolumn{2}{|c|}{ Pre } & \multicolumn{2}{|c|}{ Post } & \multirow{2}{*}{$t$} & \multirow{2}{*}{$d f$} & \multirow{2}{*}{$p$} \\
\hline & $\overline{\mathbf{X}}$ & $S D$ & $\overline{\mathbf{X}}$ & $S D$ & & & \\
\hline $\begin{array}{l}\text { Engineering } \\
\text { Pedagogical } \\
\text { Content Knowledge } \\
\text { Self-Efficacy (KS) }\end{array}$ & 4.30 & 1.17 & 5.42 & 0.70 & - & - & $<0.001$ \\
\hline $\begin{array}{l}\text { Engineering } \\
\text { Engagement } \\
\text { Self-Efficacy (ES) }\end{array}$ & 4.86 & 1.35 & 5.71 & 0.54 & - & - & 0.005 \\
\hline $\begin{array}{l}\text { Engineering } \\
\text { Disciplinary } \\
\text { Self-Efficacy (DS) }\end{array}$ & 4.60 & 1.29 & 5.53 & 0.69 & - & - & $<0.001$ \\
\hline $\begin{array}{l}\text { Engineering } \\
\text { Outcome Expectancy } \\
\text { (OE) }\end{array}$ & 4.42 & 1.03 & 5.08 & 0.87 & - & - & 0.003 \\
\hline TESS Overall Score & 4.49 & 1.05 & 5.42 & 0.58 & 2.07 & 23 & $<0.001$ \\
\hline
\end{tabular}

Table 5. Changes in Teaching Engineering Self-Efficacy for 2019 Participants $(N=15)$.

\begin{tabular}{|c|c|c|c|c|c|c|c|}
\hline \multirow[t]{2}{*}{ Construct } & \multicolumn{2}{|c|}{ Pre } & \multicolumn{2}{|c|}{ Post } & \multirow{2}{*}{ 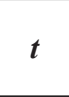 } & \multirow{2}{*}{$d f$} & \multirow{2}{*}{$p$} \\
\hline & $\overline{\mathbf{X}}$ & $S D$ & $\overline{\mathbf{X}}$ & $S D$ & & & \\
\hline $\begin{array}{l}\text { Engineering } \\
\text { Pedagogical } \\
\text { Content Knowledge } \\
\text { Self-Efficacy (KS) }\end{array}$ & 3.42 & 1.19 & 5.63 & 0.53 & - & - & $<0.001$ \\
\hline $\begin{array}{l}\text { Engineering } \\
\text { Engagement } \\
\text { Self-Efficacy (ES) }\end{array}$ & 4.29 & 0.84 & 5.73 & 0.39 & - & - & $<0.001$ \\
\hline $\begin{array}{l}\text { Engineering } \\
\text { Disciplinary } \\
\text { Self-Efficacy (DS) }\end{array}$ & 4.57 & 0.84 & 5.71 & 0.45 & - & - & $<0.001$ \\
\hline $\begin{array}{l}\text { Engineering } \\
\text { Outcome Expectancy } \\
\text { (OE) }\end{array}$ & 3.92 & 0.93 & 5.16 & 0.64 & - & - & $<0.001$ \\
\hline TESS Overall Score & 3.93 & 0.79 & 5.56 & 0.36 & 2.14 & 14 & $<0.001$ \\
\hline
\end{tabular}

ticipants were asked to provide classroom update statements over how has NEET influenced your students? Participants provided the following statements:

- 2019 Participant: "NEET has influenced my students due to the intricacies that were offered to me in the spring class. My students are more involved and interested in science due to my deeper understanding of the engineering design process and nanotechnology."

- 2019 Participant: "Students love the opportunity to collaborate and bounce ideas off each other. Again, there is much content to cover in AP-Biology; however, I try whenever possible to have the students work in groups and share out what they have done with the rest of the class. This allows them to take ownership of the learning and be more engaged."

- 2019 Participant: "Honestly, my students took motivation from my team's poster that I have in the classroom. Just seeing it and the work that was accomplished pushes them to do more in science class. They are more engaged in our PBL and take the subject serious[ly]."

- 2018 Participant: "Through NEET I was able to practice my engineering design skills, which lead to better implementation of project-based learning into the class.

Table 6. Teaching Engineering Self-Efficacy Scale Relative Gains by Construct and Year.

\begin{tabular}{lcc}
\hline & \multicolumn{2}{c}{ Relative \% Gain } \\
\cline { 2 - 3 } & 2018 & 2019 \\
\hline Engineering Pedagogical Content Knowledge & $26 \%$ & $65 \%$ \\
Self-Efficacy (KS) & & \\
Engineering Engagement Self-Efficacy (ES) & $17 \%$ & $34 \%$ \\
Engineering Disciplinary Self-Efficacy (DS) & $20 \%$ & $25 \%$ \\
Engineering Outcome Expectancy (OE) & $15 \%$ & $32 \%$ \\
TESS Overall Score & $\mathbf{2 1 \%}$ & $\mathbf{4 1 \%}$ \\
\hline
\end{tabular}


Students were also able to complete more labs, due to the ability for collaboration and idea sharing between teachers. Students were also given more up to date scientific information about nanotechnology, water issues in the Houston area, and they had more hands on experience in problem solving as a result of the lessons I learned at NEET."

- 2018 Participant: "NEET has opened students' eyes to practical application of engineering design and introduced how real scientists are trying to solve today's problems."

- 2018 Participant: "NEET has helped me to create an environment where students think outside the box. They ask more questions and have become more inventive."

\section{DISCUSSION}

This study aimed to determine if a long-term course in engineering design focusing on water and nanotechnology would increase in-service teachers' self-efficacy and outcome expectancy to teach engineering. As shown in the TESS data analysis, this course significantly increases teachers' self-efficacy in all five constructs. While there were substantial percentage gains in each construct, the largest was in Engineering Pedagogical Content Knowledge Self-efficacy (KS) with $65 \%$ gain and the smallest, at $15 \%$ gain, in Outcome Expectancy (OE). According to Tschannen-Moran et al. (1998), "self-efficacy answers the question: Do I have the ability to organize and execute the actions necessary to accomplish a specific task at the desired level? The outcome question is, if I accomplish the task at that level, what are the likely consequences?" It is common in teaching self-efficacy studies to see gains in self-efficacy but no gain in outcome expectancy. This lack of gain was the Coppola study case, where they used TESS to study engineering coursework on pre-service teachers' self-efficacy.

Several facets of the NEET course are unique and may contribute to the observed positive shifts in teacher self-efficacy and outcome expectancy. First is the program's duration, which takes place over a semester with 45 hours of contact time. This was not a short workshop or intervention, and the teachers had time to go through a full engineering design course. This PD is different from most K-12 engineering programs, which tend to be in the summer and range from a week or longer, including Engineering is Elementary PD and Project Lead the Way (Capobianco et al., 2018; Yoon, So Yoon et al., 2013). Cunningham (2009) showed changes in elementary teachers' reports about their content knowledge, pedagogy, and student engagement as a result of participating in the Engineering is Elementary (EiE) professional development workshops (Nathan et al., 2011). For example, Project Lead The Way (PLTW) offers four years of curriculum that introduces high school students to engineering and technology principles in the high school setting and has several teacher PD models from two-day, two-week, online, or blended programs. While these studies had positive qualitative and quantitative outcomes, there was no direct analysis of the PD models' impact on teacher self-efficacy in engineering.

Another difference in the design of the NEET course is the inclusion of authentic teacher teams. In the NEET course, teachers in teams of two to four had to struggle over the semester on novel ill-defined problems, like their students, to collaborate and share responsibilities. The inclusion of CATME in the course helped with teamwork. CATME also lessened the load on the lead facilitator of the course since the team could see the peer evaluations and issues to be resolved without intervention.

The NEET course was led by a diverse team of educators, including a high school teacher who teaches AP Environmental Science, graduate students who consulted on the design teams, faculty lectures on nanotechnology-enabled water treatment topics, and a leader who has over a decade of expertise as a full-time teacher educator. The NEET teaching staff brought a diverse skill set to the course that included expertise in inquiry science teaching, engineering design, water purification technologies, K-12 education standards, and understood the constraints of a K-12 classroom teacher in school districts area.

With 16 participants in the 2019 cohort, the lower student-to-teacher ratio provided more opportunities for individualized formative assessments during course discussions. With the addition of the graduate and postdoctoral mentors, each project group had a reliable contact for a more profound reflection of design ideas. Research shows that when working with diverse students or students from low-socioeconomic backgrounds, they are likely to have higher achievement when the student-to-instructor ratio is reduced (Copper, 1989).

Principals and STEM district leaders attended the NEET engineering showcase, the end of the program presentation session that provides an opportunity to disseminate their project designs and ideas, bringing learned engineering skills to the classroom. The teachers present research posters and their built prototypes to K-12 leaders, research scientists, and engineers at the showcase. The collection of various stokeholds is purposely designed to generate excitement about the program and to enhance motivation and lower barriers for K-12 engineering potentially.

\section{Limitations and Future Directions of the Study.}

Self-Selection. Engineering is relatively new in the K-12 space, so the teachers who elected to spend three hours a week for a full semester in an evening class after teaching the 
entire day were an incredibly motivated group. The self-selection may also indicate that these teachers are early adopters of engineering practices and have strong self-confidence in their teaching skills in general, and this program helped them develop their self-confidence in engineering specifically. It would be interesting to see if similar outcomes would be found in a non-self-selecting group, such as a mandated engineering design course in a teacher preparation program.

Self-Efficacy. We noted that in 2018 and 2019, NEET course teachers exhibited significant gains in teaching engineering self-efficacy. In particular, we saw unusually large gains in the 2019 TESS survey results. As shown in Table 2, 56.3\% of the teachers in the 2019 cohort taught in districts identified as high needs (over $40 \%$ economically disadvantaged), whereas in 2018 , over $80 \%$ of the teachers taught in these high need schools. It is quite possible that teachers who teach in schools with a high percentage of economically disadvantaged students may face more constraints and would have a lower outcome expectancy than those who teach in wealthier districts since student socioeconomic status, family background, or home environment can affect a teachers' ability to impact student achievement. This decrease in teachers representing high-needs schools could partially explain the difference between 2018 and 2019 TESS outcomes.

Implementation. Due to funding limitations, classroom observations were not performed, which is an essential tool for understanding how teachers utilized the course's aspects with students. Instead, an electronic implementation survey was sent to the teachers in the semester following their spring course participation. Unfortunately, this survey's response rate was only $36 \%$ ( 9 out of 25 ) in 2018 and $44 \%$ ( 7 out of 16). At least 5 of the teachers in the 2018 cohort have left the classroom through promotions to district administrators, are pursuing advanced degrees as full-time students, have taken family leave, or have left teaching for other careers. Several teachers reported that environmental science classes were not offered at their schools this year, that their administrators changed their teaching assignments, or that there was resistance from their peers or administrators. We learned some of the constraints teachers face when implementing engineering design and PBLs in their classrooms from these surveys. However, most (81\%) reported introducing PBLs in their classrooms despite these constraints.

Program Design. The NEET course design provides teachers with 3-hour weekly classroom meetings to work with their teammates and time between these weekly sessions to read the assignments and think about the content while they are teaching students. It is not clear if the program's outcomes would be as notable if offered during a summer institute with the same number of content hours. However, we plan to offer this course as a two week, 45-hour summer session in the future to investigate if there is an effect on teacher self-efficacy outcomes in shorter course design.

In general, we believe that access to clean water for everyone in the world is a compelling topic. This topic, combined with the need to develop complex problem-solving skills, creates a platform where teachers can learn how to teach engineering design confidently.

\section{CONCLUSION}

This paper shares NEET's program design, which focused on teachers introducing both PBL and the engineering design process to K-12 STEM teachers and how the new TESS instrument can be used to assess teacher change. By providing the participants with a long-term PD course built using Wlodkowski's five attributes for adult motivation, teachers had significant improvements in overall engineering self-efficacy and their belief indirectly affecting student engineering engagement, outcome expectancy (Wlodkowski and Ginsberg, 2017). This motivational shift suggests that leading similar professional development opportunities to NEET can increase educators' content knowledge and empower them to use PBL in their classrooms.

\section{AUTHOR INFORMATION \\ Corresponding Author}

Carolyn Nichol, Ph.D., Rice University, 6100 Main Street, Houston, TX 77005. cnichol@rice.edu

\section{Author Contributions}

The manuscript was written through contributions of all authors. All authors have given approval to the final version of the manuscript.

\section{FUNDING SOURCES}

This work was supported by an NSF award \#EEC1449500. Any opinions, findings, and conclusions or recommendations expressed in this material are those of the authors and do not necessarily reflect the views of the National Science Foundation.

\section{ABBREVIATIONS}

AP: Advanced Placement; CATME: Comprehensive Assessment of Team Member Effectiveness; DET: Design, Engineering, and Technology; EiE: Engineering is Elementary; EOSS: Engineering Outreach Self-Efficacy Scale; ES: Engagement Self-Efficacy; KS: Content Knowledge Self-Efficacy; NEET: NanoEnvironmental Engineering for Teachers; NSF: National Science Foundation; OE: 
Outcome Expectancy; PBL: Project-Based Learning; PD: Professional Development; PEIMS: Public Education Information Management System; STEM: Science, Technology, Engineering, and Math; TES: Total Engineering Self-Efficacy; TESS: Teaching Engineering Self-Efficacy Scale

\section{REFERENCES}

Anning, A. (1994). Dilemmas and opportunities of a new curriculum: Design and technology with Young Children. International Journal of Technology and Design Education, 4(2), 155-177. https://doi.org/10.1007/BF01204545

Ashton, P. T., and Webb, R. B. (1986). Making a difference: Teachers' sense of efficacy and student achievement. Longman Publishing Group.

Bandura, A. (1997). Self-efficacy: The exercise of control. Macmillan.

Barron, B. J., Schwartz, D. L., Vye, N. J., Moore, A., Petrosino, A., Zech, L., and Bransford, J. D. (1998). Doing with understanding: Lessons from research on problem-and project-based learning. Journal of the Learning Sciences, 7(34), 271-311. https://doi.org/10.1080/10508406.1998.9672 056

Bayraktar, S. (2011). Turkish pre-service primary school teachers' science teaching efficacy beliefs and attitudes toward science: The effect of a primary teacher education program. School Science and Mathematics, 111(3), 83-92. https:// doi.org/10.1111/j.1949-8594.2010.00065.x

Becker, K., and Park, K. (2011). Effects of integrative approaches among science, technology, engineering, and mathematics (STEM) subjects on students' learning: A preliminary meta-analysis. Journal of STEM Education: Innovations and Research, 12(5), 23-37.

Beier, M. E., Kim, M. H., Saterbak, A., Leautaud, V., Bishnoi, S., and Gilberto, J. M. (2019). The effect of authentic project-based learning on attitudes and career aspirations in STEM. Journal of Research in Science Teaching, 56(1), 3-23. https://doi.org/10.1002/tea.21465

Bell, S. (2010). Project-based learning for the 21st century: Skills for the future. The Clearing House: A Journal of Educational Strategies, Issues and Ideas, 83(2), 39-43. https:// doi.org/10.1080/00098650903505415

Boyle, B., Lamprianou, I., and Boyle, T. (2005). A longitudinal study of teacher change: What makes professional development effective? Report of the second year of the study. School Effectiveness and School Improvement, 16(1), 1-27. https://doi.org/10.1080/09243450500114819

Brophy, S., Klein, S., Portsmore, M., and Rogers, C. (2008). Advancing engineering education in P-12 classrooms. Journal of Engineering Education, 97(3), 369-387. https://doi. org/10.1002/j.2168-9830.2008.tb00985.x
Buss, R. R. (2010). Efficacy for teaching elementary science and mathematics compared to other content. School Science and Mathematics, 110(6), 290-297. https://doi. org/10.1111/j.1949-8594.2010.00037.x

Capobianco, B. M., DeLisi, J., and Radloff, J. (2018). Characterizing elementary 'teachers' enactment of high-leverage practices through engineering design-based science instruction. Science Education, 102(2), 342-376. https://doi. org/10.1002/sce. 21325

Caprara, G. V., Barbaranelli, C., Steca, P., and Malone, P. S. (2006). Teachers' self-efficacy beliefs as determinants of job satisfaction and students' academic achievement: A study at the school level. Journal of School Psychology, 44(6), 473490. https://doi.org/10.1016/j.jsp.2006.09.001

Capraro, R. M., Capraro, M. M., Scheurich, J. J., Jones, M., Morgan, J., Huggins, K. S., Corlu, M. S., Younes, R., and Han, S. (2016). Impact of sustained professional development in STEM on outcome measures in a diverse urban district. The Journal of Educational Research, 109(2), 181-196. https://doi.org/10.1080/00220671.2014.936997

Carberry, A. R., Lee, H., and Ohland, M. W. (2010). Measuring engineering design self-efficacy. Journal of Engineering Education, 99(1), 71-79. https://doi. org/10.1002/j.2168-9830.2010.tb01043.x

Cirak, F., Scott, M. J., Antonsson, E. K., Ortiz, M., and Schröder, P. (2002). Integrated modeling, finite-element analysis, and engineering design for thin-shell structures using subdivision. Computer-Aided Design, 34(2), 137-148. https:// doi.org/10.1016/S0010-4485(01)00061-6

Copper, H. M. (1989). Does reducing student-to-instructor ratios affect achievement? L Erlbaum Associates. https://doi. org/10.1207/s15326985ep2401_3

Creese, R. (1987). A project-centered engineering program. Engineering Education, 78(2), 100-104.

Cunningham, C. M. (2009). Engineering is elementary. The Bridge, 30(3), 11-17.

Daugherty, J. L. (2008). Engineering-oriented professional development for secondary level teachers: A multiple case study analysis. https://doi.org/10.21061/jte.v21i1.a.1

Deehan, J. (2016). The science teaching efficacy belief instruments (STEBI A and B): A comprehensive review of methods and findings from 25 years of science education research. Springer. https://doi.org/10.1007/978-3-319-42465-1_3

Desimone, L. M. (2009). Improving impact studies of 'teachers' professional development: Toward better conceptualizations and measures. Educational Researcher, 38(3), 181199. https://doi.org/10.3102/0013189X08331140

Desimone, L. M. (2011). A primer on effective professional development. Phi Delta Kappan, 92(6), 68-71. https://doi. org/10.1177/003172171109200616 
Desimone, L. M., Porter, A. C., Garet, M. S., Yoon, K. S., and Birman, B. F. (2002). Effects of professional development on 'teachers' instruction: Results from a three-year longitudinal study. Educational Evaluation and Policy Analysis, 24(2), 81-112. https://doi.org/10.3102/01623737024002081

Diaconu, D. V., Radigan, J., Suskavcevic, M., and Nichol, C. (2012). A multi-year study of the impact of the rice model teacher professional development on elementary science teachers. International Journal of Science Education, 34(6), 855-877.

Felder, R. M., Brent, R., and Prince, M. J. (2011). Engineering instructional development: Programs, best practices, and recommendations. Journal of Engineering Education, 100(1), 89-122. https://doi.org/10.1002/j.2168-9830.2011. tb00005.x

Fogg-Rogers, L., and Moss, T. (2019). Validating a scale to measure 'engineers' perceived self-efficacy for engineering education outreach. PloS One, 14(10) https://doi.org/10.1371/ journal.pone. 0223728

Gan, D., and Gal, A. (2018). Self-efficacy for promoting EfS among pre-service teachers in Israel. Environmental Education Research, 24(7), 1062-1075. https://doi.org/10.108 $0 / 13504622.2017 .1396288$

Ginns, I. S., and Watters, J. J. (1999). Beginning elementary school teachers and the effective teaching of science. Journal of Science Teacher Education, 10(4), 287-313. https://doi. org/10.1023/A:1009442125203

Gribble, J. R. (2014). What it takes: Pre-k-12 design principles to broaden participation in science, technology, engineering and mathematics, ed. ().Building Engineering and Science Talent. http://www.bestworkforce.org/publications

Guo, Y., Justice, L. M., Sawyer, B., and Tompkins, V. (2011). Exploring factors related to preschool 'teachers' self-efficacy. Teaching and Teacher Education, 27(5), 961-968. https:// doi.org/10.1016/j.tate.2011.03.008

Guskey, T. R. (2002). Professional development and teacher change. Teachers and Teaching, 8(3), 381-391. https:// doi.org/10.1080/135406002100000512

Hailey, C., Erekson, T., Becker, K. H., and Thomas, M. (2005). National Center for Engineering and Technology Education. Hosted by Utah State University Libraries.

Hmelo-Silver, C. E. (2004). Problem-based learning: What and how do students learn? Educational Psychology Review, 16(3), 235-266. https://doi.org/10.1023/B:EDPR.0000034022.16470.f3

Hong, T., Purzer, Ş, and Cardella, M. E. (2011). A psychometric re-evaluation of the design, engineering and technology (DET) survey. Journal of Engineering Education, 100(4), 800-818.https://doi.org/10.1002/j.2168-9830.2011. tb00037.x

Hoy, A. W., Hoy, W. K., and Davis, H. A. (2009). Teachers' self-efficacy beliefs. In K. Wentzel and A Wigfield (Eds.), Handbook of motivation at schools (pp. 627-652) Routledge Taylor and Francis Group.
Jemimah L. Young University of North Texas. Maximizing Opportunities to Enroll in Advanced High School Science Courses: Examining the Scientific Dispositions of Black Girls

Lieberman, A. (1995). Practices that support teacher development: Transforming conceptions of professional learning. Innovating and Evaluating Science Education, 67-78.

Loignon, A. C., Woehr, D. J., Thomas, J. S., Loughry, M. L., Ohland, M. W., and Ferguson, D. M. (2017). Facilitating peer evaluation in team contexts: The impact of frame-of-reference rater training. Academy of Management Learning and Education, 16(4), 562-578. https://doi.org/10.5465/ amle.2016.0163

Lotter, C., Smiley, W., Thompson, S., Dickensonand, T. (2016). The impact of a professional development model on middle school science teachers' efficacy and implementation of inquiry. International Journal of Science Education, 38(18), 2712-2741. https://doi.org/10.1080/09500693.20 16.1259535

Loughry, M. L., Ohland, M. W., and Woehr, D. J. (2014). Assessing teamwork skills for assurance of learning using CATME team tools. Journal of Marketing Education, 36(1), 5-19. https://doi.org/10.1177/0273475313499023

Madden, A., Hochella, M. F., Glasson, G. E., Grady, J. R., Bank, T. L., Green, A. M., Norris, M. A., Hurst, A. N., and Eriksson, S. C. (2011). Welcome to Nanoscience: Interdisciplinary Environmental Explorations, Grades 9-12. NSTA Press Book.

Mills, J. E., and Treagust, D. F. (2003). Engineering education is Problem-Based or Project-Based learning the answer? Australasian Journal of Engineering Education, http:// www.aaee.com.au/journal/2003/mills_treagust03.pdf

Moslemi, N., and Mousavi, A. (2019). A psychometric re-examination of the science teaching efficacy and beliefs instrument (STEBI) in a Canadian context. Education Sciences, 9(1), 17. https://doi.org/10.3390/educsci9010017

Nathan, M. J., Atwood, A. K., Prevost, A., Phelps, L. A., and Tran, N. A. (2011). How professional development in Project Lead the Way changes high school STEM 'teachers' beliefs about engineering education. Journal of Pre-College Engineering Education Research (J-PEER), 1(1), 3. https://doi.org/10.7771/2157-9288.1027

National Academy of Engineering and National Research Council. (2009). Engineering in K-12 education: Understanding the status and improving the prospects. https://doi. org/10.17226/12635

NGSS Leads States. (2013). Next Generation Science Standards. National Academies Press.

Nichol, C. A., and Crawford, C. A., Loyo-Rosales, J., Chow, A., and Obenland, C. (2018, June), Nano-environmental Engineering for Teachers (Work in Progress), Paper presented at 2018 ASEE Annual Conference and Exposition, Salt Lake City, Utah. https://peer.asee.org/29642 
Padilla, M. J. (1990). The Science process skills. Research Matters - to the Science Teacher, 9004 http://www.educ.sfu.ca/ narstsite/publications/research/skill.htm

Perkins Coppola, M. (2019). Preparing pre-service elementary teachers to teach engineering: Impact on self-efficacy and outcome expectancy. School Science and Mathematics, 119(3), 161-170. https://doi-org.ezproxy.rice.edu/10.1111/ ssm. 12327

Prince, M. J., and Felder, R. M. (2006). Inductive teaching and learning methods: Definitions, comparisons, and research bases. Journal of Engineering Education, 95(2), 123-138. https://doi.org/10.1002/j.2168-9830.2006.tb00884.x

Riggs, I. M., and Enochs, L. G. (1990). Toward the development of an elementary teacher's science teaching efficacy belief instrument. Science Education, 74(6), 625-637. https://doi. org/10.1002/sce.3730740605

Skaalvik, E. M., and Skaalvik, S. (2007). Dimensions of teacher self-efficacy and relations with strain factors, perceived collective teacher efficacy, and teacher burnout. Journal of Educational Psychology, 99(3), 611. https://doi. org/10.1037/0022-0663.99.3.611

Summers, J. J., Davis, H. A., and Hoy, A. W. (2017). The effects of teachers' efficacy beliefs on students' perceptions of teacher relationship quality. Learning and Individual Differences, 53, 17-25. https://doi.org/10.1016/j.lindif.2016.10.004

Supovitz, J. A., and Turner, H. M. (2000). The effects of professional development on science teaching practices and classroom culture. Journal of Research in Science Teaching: The Official Journal of the National Association for Research in Science Teaching, 37(9), 963-980. https:// doi.org/10.1002/1098-2736(200011)37:9<963::AIDTEA6 $>3.0 . \mathrm{CO} ; 2-0$

Texas Education Agency Snapshot 2018. (2019). Retrieved from https://rptsvr1.tea.texas.gov/perfreport/snapshot/2018/index.html

Tschannen-Moran, M., Hoy, A. W., and Hoy, W. K. (1998). Teacher efficacy: Its meaning and measure. Review of Educational Research, 68(2), 202-248. https://doi. org/10.3102/00346543068002202

Tschannen-Moran, M., and Johnson, D. (2011). Exploring literacy 'teachers' self-efficacy beliefs: Potential sources at play. Teaching and Teacher Education, 27(4), 751-761. https:// doi.og/10.1016/j.tate.2010.12.005

Valtorta, C. G., and Berland, L. K. (2015). Math, science, and engineering integration in a high school engineering course: A qualitative study. Journal of Pre-College Engineering Education Research, 5(1), 15-29. https://doi. org/10.7771/2157-9288.1087

Van Veen, K., Zwart, R., and Meirink, J. (2012). What makes teacher professional development effective? A literature review. Teacher learning that matters (pp. 23-41). Routledge.
Wheatley, K. F. (2002). The potential benefits of teacher efficacy doubts for educational reform. Teaching and Teacher Education, 18(1), 5-22. https://doi.org/10.1016/S0742051X(01)00047-6

Wlodkowski, R. J. (1999). Enhancing adult motivation to learn: A comprehensive guide for teaching all adults (Rev. ed.). San Francisco: Jossey-Basss

Wlodkowski, R. J., and Ginsberg, M. B. (2017). Enhancing adult motivation to learn: A comprehensive guide for teaching all adults. John Wiley and Sons.

Yoon, S. Y., Diefes-Dux, H., and Strobel, J. (2013). First-year effects of an engineering professional development program on elementary teachers. American Journal of Engineering Education, 4(1), 67-84. https://doi.org/10.19030/ajee. v4i1.7859

Yoon, S. Y., Evans, M. G., and Strobel, J. (2014). Validation of the teaching engineering self-efficacy scale for K-12 teachers: A structural equation modeling approach. Journal of Engineering Education, 103(3), 463-485. https://doi. org/10.1002/jee.20049 